\title{
The value of librarians for clinical and health governance (a
} view from Europe)

\begin{tabular}{|r|l|}
\hline Journal: & International Journal of Health Governance \\
\hline Manuscript ID & Draft \\
\hline Manuscript Type: & Original Article \\
\hline Keywords: & $\begin{array}{l}\text { Clinical governance < Health Service Quality Assurance, Organizational } \\
\text { development for effective clinical governance < Health Service Quality } \\
\text { Assurance, Organizational learning < Health Service Quality Assurance, } \\
\text { Knowledge management < Informatics, Information technology < } \\
\text { Informatics, Evidence-based practice < Health Service Quality Assurance }\end{array}$ \\
\hline
\end{tabular}




\title{
The value of librarians for clinical and health governance (a view from Europe)
}

\begin{abstract}
Purpose

Governance of health care organisations and health systems require many different competencies, with a great emphasis on evidence and information governance, which are traditional fields of librarians' expertise. However, stakeholders are unaware of how health and hospital libraries are contributing with specific activities and what the trends are in library support for health/clinical governance in Europe, mainly because traditional methods of measuring impact are restricted to specific library activities or are not showing direct impact long term.
\end{abstract}

\section{Design/methodology/approach}

A model combining components of clinical and health governance $(\mathrm{C} / \mathrm{HG})$, related library activity types, and the possible impact was developed based on a literature review and tested by a European expert panel. A web-based survey was offered to the members of the European Association for Health Information and Libraries (EAHIL) to offer further insight into activities and examples of contribution to $\mathrm{C} / \mathrm{HG}$.

\section{Findings}

Librarians from 25 European countries participated in the survey. The model proves that librarians in Europe are involved in supporting most identified components of clinical and health governance, with examples of clinical effectiveness and research, education and training, patient and public involvement, partnership engagement, formulating strategic direction etc.

\section{Research limitations/implications}

We were unable to cover the roles of libraries in all European countries in this paper, but dialogue and research will continue within the EAHIL group.

\section{Practical implications}

These findings will help decision makers on different levels of the health system to improve their practices by incorporating library functions and services in different components of $\mathrm{C} / \mathrm{HG}$. This would enable libraries to develop emerging roles in clinical and health governance more formally and reduce risks of closure or funding cuts.

\section{Originality/value}

No such comparative research has been undertaken before, looking at what activities and tasks libraries undertake to support $\mathrm{C} / \mathrm{HG}$. This research has highlighted valuable services and tools that can be replicated in libraries across health and care organisations, and at the same time promote libraries and librarians as significant actors in organisational governance.

Keywords clinical governance, health governance, library services, librarians, health and care organisations, knowledge organization, information governance. 
article classification Research article

\section{Introduction}

Governance of health care organisations require many different competencies, including methods of locating evidence of best practice, integrating best evidence into care pathways, auditing of clinical practice, handling of complaints, adverse event analysis, and proactive risk management. Few health and care practitioners have the complete set of those competencies, therefore, they often need support and training from other professional staff. Librarians traditionally play important roles both in locating best evidence and in training others, and although new roles of libraries are emerging, it has been difficult to identify what activities they undertake to support clinical and health governance $(\mathrm{C} / \mathrm{HG})$ and how to evaluate their impact.

The aim of this paper is to research how librarians in different types of organisations are contributing to all components of $\mathrm{C} / \mathrm{HG}$ with specific types of activities, where are the gaps that they can fill with new products and services, and also to identify common trends in library support for $\mathrm{C} / \mathrm{HG}$ in Europe.

Our literature review retrieved no recent publications providing a broad picture of librarians' value for all aspects of clinical and specifically health governance, though many professional papers are devoted to their involvement in such components as evidence-based practice, lifelong learning, risk management, and other emerging roles (e.g. "Librarians Embedded in Ethics", "Mining Data in Electronic Health Record Systems: Opportunities for Librarians", "Research Information Management: Defining RIM and the Library's Role", "Isn't it the right time for librarians to officially join clinical trial teams?").

It is not always known or clear to stakeholders (including decision-makers) what libraries and librarians can provide and where their services fit. Authors from the US showed that though medical librarians "possess expertise to navigate various search resources and can investigate inquiries during health information system project lifecycles" they were not included in implementation and research teams (Saimbert, 2010). Research from Italy about hospital-based HTA stated that "the librarian is almost never represented within the HTA evaluation group" (Balduini et al, 2013)." Information professionals carry out many activities involved in mobilising research into practice but this is often not recognised" concluded recent research on public health decision making in the UK and Scotland (van der Graaf, 2018).

Libraries in health care organisations research and measure their impact on health services and patient outcomes to demonstrate how exactly they contribute to organisational objectives. The Rochester study (Marshall, 1992) was among the first to relate information services provided by librarians to patient care outcomes. Since then there was a large number of papers published on clinical librarian services within primary and secondary care, including systematic reviews and other evaluations (Klein, 1994; Weightman, 2005; Bryant, 2006; Sutton, 2011; Brettle et al, 2011; Marshall, 2014; Perrier et al, 2014). 
The early systematic reviews found limited evidence of effectiveness and impact of clinical librarians, because of poor quality of reporting, scale and design of many studies though they showed that clinical librarian services were well used and liked by clinicians. The study (Brettle et al, 2011) concentrated on methods of clinical librarian service evaluations, and stated that the quality of studies was improving, but "more work is needed on reducing bias and providing evidence of specific impacts on patient care". It concluded that "the Critical Incident Technique as part of a mixed method approach appears to offer a useful approach to demonstrating impact."

A special attention was payed to developing tools to measure impact and value of library services (Urquhart and Turner, 2016; Urquhart and Tbaishat, 2016). Measures to show financial impact were: value of time saved, value of resource collection against cost of alternative sources, cost avoidance and revenue generated through assistance on grant submissions. "Few papers provided an insight into the longer term impact on the library service resulting from submitting return on investment (ROI) or other financial impact statements." (Madden, 2016). Recently a generic tool to routinely measure the impact of health library services was developed and tested (Ayre et al, 2018).

Services provided by librarians in healthcare setting are complex interventions "made up of a number of elements and wide ranging potential outcomes which are affected by other factors within the organisation. An experimental design to ascertain their effectiveness and impact is inappropriate and would be compromised by a wide range of confounding variables", that is why "demonstrating the direct impact of clinical librarian services on patient care is extremely difficult to prove, studies should determine if clinical librarians make a contribution to patient care rather than a direct impact" (Brettle, 2015).

The Critical Incident Technique (which asks for responses regarding a particular use of the library services), together with interviews and questionnaires showed "that clinical librarians contribute to a wide range of outcomes in the short and longer term and really do make a difference, in particular around direct contributions to choice of intervention (36\%); diagnosis (26\%); quality of life (25\%), increased patient involvement in decision making (26\%) and cost savings and risk management including avoiding tests, referrals, readmissions and reducing length of stay (28\%) (Brettle et al, 2015; Brettle et al, 2016). They were able to prove that clinical librarians improve quality and help save money as well as affecting patient care directly.

Libraries are developing other ways of reporting impact, e.g. through case studies (prepared and published both by librarians and health services staff): Knowledge Management Stories (https://tinyurl.com/y9lqu4xy); Impact Case Studies (https://tinyurl.com/ydgbgydl); Library Impact - Case Studies (https://tinyurl.com/yd4r9e4k).

Librarians working in the variety of healthcare organizations increasingly need to justify their work and the very existence of their libraries, and research findings such as these are important, as are tools to evaluate impact. Still there are limitations to their practical implications. Types of interventions considered in library impact research are usually either very broad (literature search; literature search and critical appraisal; literature search and critical appraisal/synthesis of evidence; training; journal club) (Brettle et al, 2016), or are using more traditional categorization based on 
library services (collections, research and publishing support services, personal services, teaching services and guidelines) (Halkoaho et al., 2018).

A more detailed list of library activity types related to specific components of $\mathrm{C} / \mathrm{HG}$ could help all stakeholders to better understand how libraries can achieve impact shown in the previous studies, and encourage librarians from other countries to develop new products and services. Then evaluation tools can be developed to show short and long-term impact of such activities. The survey research method was chosen to show how librarians are contributing to components of C/HG with specific types of activities and also to identify common trends in library support for $\mathrm{C} / \mathrm{HG}$ in Europe. These findings will help decision makers on different levels of the health system to improve their practices by incorporating library functions and services in different components of $\mathrm{C} / \mathrm{HG}$.

\section{Method}

In its broadest sense clinical governance is an organisation-wide approach to continuous improvement of healthcare quality by all the individuals who are involved in a patient's care. Usually it is presented to comprise the following seven components: patient and public involvement, staffing and staff management, clinical effectiveness and research (evidence-based practice), using information and IT, education and training, risk management, and audit. Based on literature search (PubMed, Google Scholar, EmeraldInsight, EAHIL conference abstracts and EAHIL journal) and job descriptions (available on the Internet) a list of library activities types related to each component of clinical governance was constructed.

Governance in the health sector refers to a wide range of steering and rule-making related functions carried out by governments and decision makers as they seek to achieve national health policy objectives. Health governance can be presented by its eight sub-functions (components): accountability, partnerships, formulating policy/ strategic direction, generating information/ intelligence, organizational adequacy/ system design, participation and consensus, regulation, transparency. Each of this eight components has a related set of tools that are used to enable them. Certain library activity types that can be incorporated in support of those tools - this list was also constructed based on literature search and authors' professional experience.

The initial list (74 types) was refined and extended by a focus group of experts (librarians and information specialists) in two rounds (first round - 26 types changed and 30 added, second round - 10 changed or added). The suggested model is presented as a 4-column table (Table 1). First column - clinical governance and health governance components. Second - examples of related clinical governance measures (Pearson, 2017) and examples of related health governance tools (Barbazza and Tello, 2014). Those were used to better understand the view of stakeholders on each component and to assign related types of library activities. Third column - related library activities types (111 types). Fourth column - established impact of library services (Brettle et al, 2016).

Based on this model a web-based survey (SurveyPlanet) was offered through the mailing list to the European members of the European Association of Health Information and libraries (EAHIL). Ethical research committee review was not required. The survey was anonymous, the two mandatory fields being the type of organisation and the target audiences (the country information 
was collected automatically). Participants (one for each organization) were asked to mark all types of activities in which they (their library) are involved, and to provide examples of those. The survey was opened for four weeks (September 2018).

\section{Table 1. Components of clinical and health governance and related types of library activities}

\section{Results}

83 participants from 25 European countries completed the survey. About third of them provided examples of their activities in support of specific components.

The largest groups were from hospitals (31.1\%) and from medical libraries $(14.3 \%)$, others represented research institutes $(10.7 \%)$, university public health or medical library $(10.7 \%)$, university teaching hospitals $(9.5 \%)$, national ministry or health agency $(8.3 \%)$, freelance librarians $(3.6 \%), 10.7 \%$ were from other types of organisations (mostly a combination of a research institute and a hospital).

By target audiences: the most frequently named groups were researchers $(89 \%)$ and physicians $(83 \%)$, then nurses $(77 \%)$, other hospital healthcare practitioners $(77 \%)$, and public health professionals $(54 \%)$, less participants stated providing services to non-hospital healthcare practitioners $(40 \%)$, patients and public (38\%), other health and non-health professional staff locally or internationally (36\%), and decision makers on all levels $(30 \%)$.

When asked about clinical governance (Figure 1), practically all the participants stated that they supported clinical effectiveness and research (98\%) and education and training $(96 \%)$; the majority supported patient and public involvement (84\%), staffing and staff management (72\%), using IT and information (77\%); less than a half were involved in risk management (38\%), and audit (32\%). Nearly half supported other aspects of clinical governance (48\%).

When asked about health governance (Figure 1): the majority stated support for partnerships (71\%) and for participation and consensus (60\%); half - for formulating policy/strategic direction (50\%) and for generating information/ intelligence (52\%). Less than half provide support for transparency $(47 \%)$, organizational adequacy/ system design (44\%), accountability (38\%), regulation (21\%). 


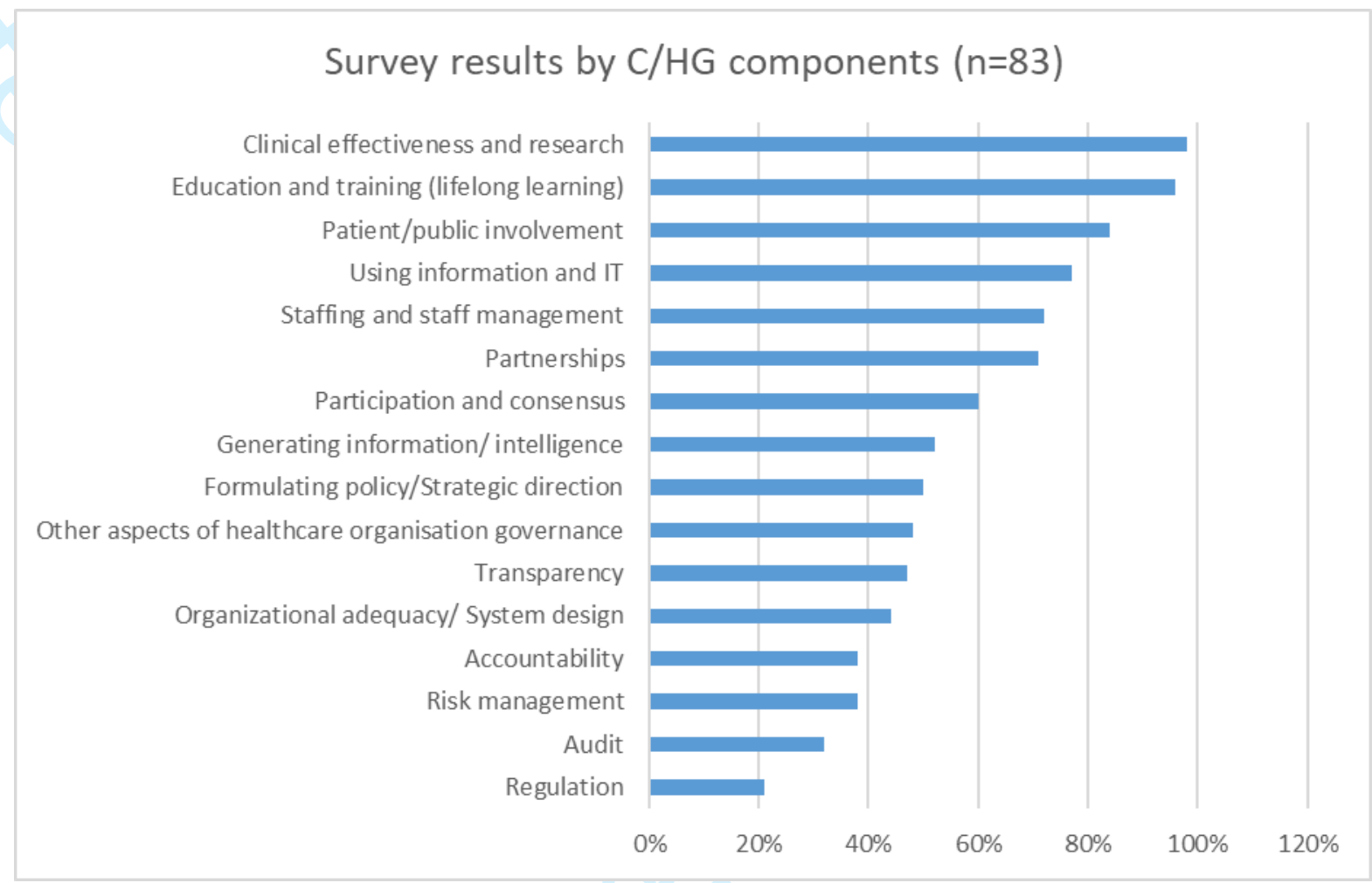

Figure 1. Survey results by $C / H G$ components

The highest number and the largest variety of library activities were reported for the libraries of National Health Agency/Health Ministry, medical libraries, and the libraries of other type of organisations (mostly a combination of a research institute and a hospital) (Figure 2).

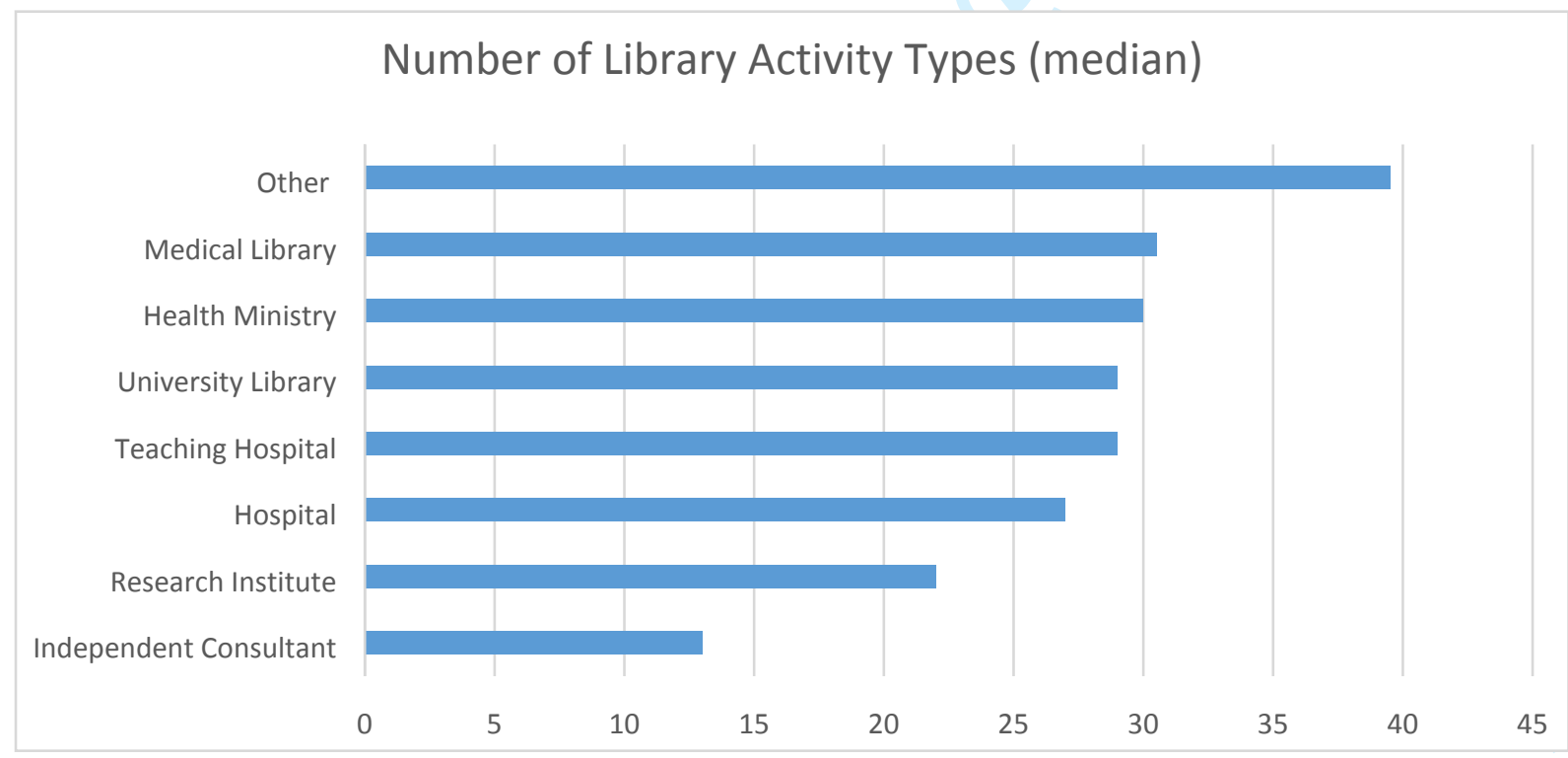

Figure 2. Median of activity types number by organisation type 


\section{Discussion}

In this section the survey results are analyzed by library activity types related to each component of $\mathrm{C} / \mathrm{HG}$, the activity types with highest percentage for each component are highlighted, and some examples provided by respondents are included. The charts present percentage for each type of activity (using the numbering from Table 1). (For full results, please contact authors).

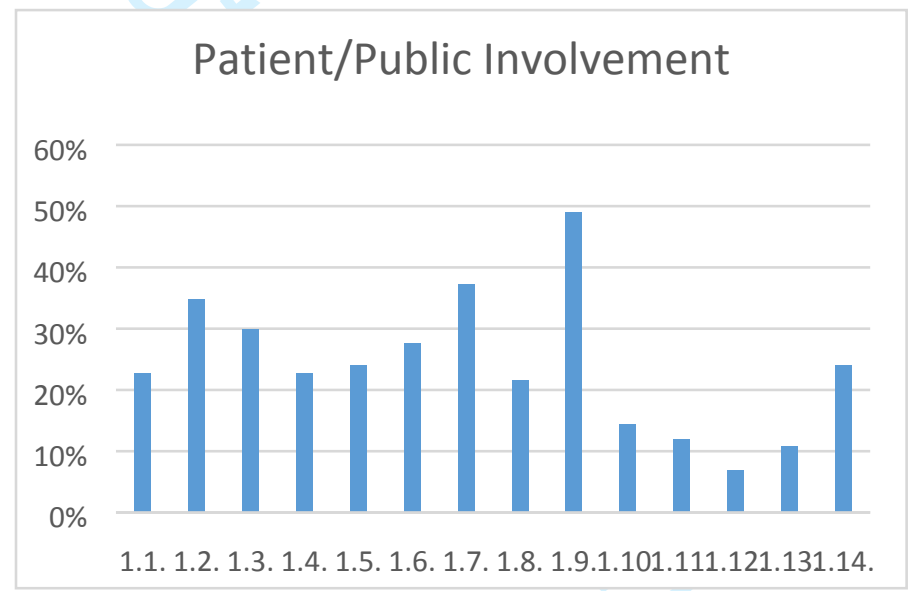

Figure 3.Survey results by activity types in support of patients/public

Patient and public involvement. Those activities are targeted both at patients/public and healthcare practitioners: (1.9.) providing information literacy training to the community (49\%); (1.7.) providing training to practitioners on consumer information and health literacy $(37.3 \%)$; (1.2.) creating resource guides for/with patients/carers and practitioners (34.9\%). Very specific role is (1.8.) involvement/ leading systematic assessment of organization's health literacy attributes (print and oral communication, navigation) $(21.6 \%)$.

Examples: "Development of a national health information portal with training courses for patient and families about reliable information sources"; "Delivering information to health professionals to help them answer queries on health products from the general public"; "Assist Health Professionals to find information in other languages suitable for non-English speaking immigrants/asylum seekers"; "Update the library website with links to online patient care association portals"; "Informational literacy courses "Reliable information - an important factor in patient empowerment" are conducted for different patient groups or patient organizations"; "We help the patients who go to the library preparing posters to be taken to the ward, in the various fields of medicine, in Italian and downloaded from reliable medical sites"; " Involved in a multiprofessional Team for planning patient education \& empowerment activities - enhancing patients in proposing health topics to discuss in group with experts".

Staffing and staff management. Though the majority stated involvement in staff development $(63.8 \%)$, the provided examples reveal that there are three different understandings of this component: mentoring, coaching and training of library staff; information literacy and similar types of training activities for health professionals; involvement in leadership and similar development programmes for health professionals $(24 \%)$ and providing information on those topics. 
Examples: "Signposting to staff \& leadership development opportunities for ENT specialists via regularly updated library-maintained notice board with conferences \& courses as well as promotion via library blog / Twitter"; "Assisting staff on management courses with their research. Alerts bulletin for leadership and management staff"; "Supporting knowledge management techniques to improve conversations (randomised coffee trials, Lego Serious Play, knowledge cafes, fish bowl conversations), run training in techniques use of and facilitation; "Working with Practice Nurses to create training tables for key competencies".

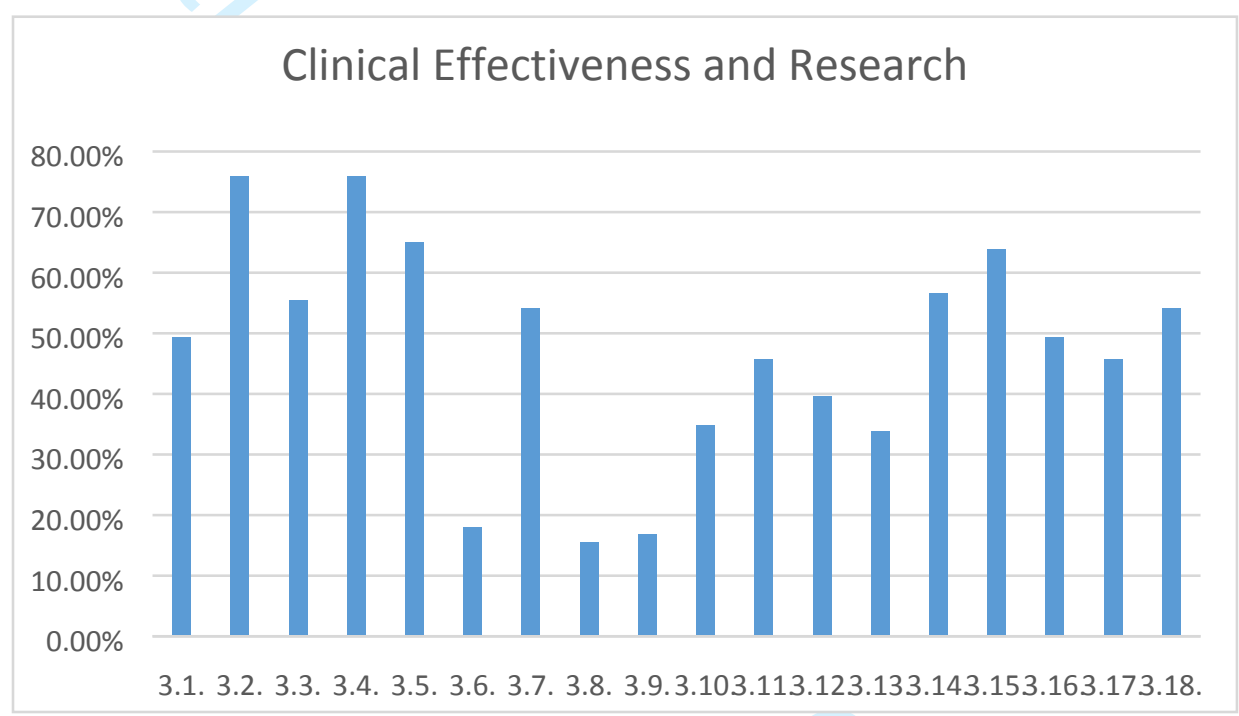

Figure 4. Survey results by activity types in support of Clinical Effectiveness and Research

Clinical effectiveness and research (evidence-based practice). The survey results support what is known from literature: practically all libraries are involved in a great variety of activities in support of this component of CG.

They organize evidence-based practice $(\mathrm{EBP})$ resources:

- (3.2.) decisions about subscriptions, negotiating license agreements (75.9\%);

- (3.3.) participating in library purchasing consortium (55.4\%).

They provide training:

- (3.4.) in quality filtering, critical analysis of literature, searching techniques (75.9\%);

- (3.15) on scholarly communication topics (54.2\%);

- (3.5.) develop database guides and instructions (65\%).

They support practice:

- (3.7.) by search for evidence and clinical guidelines on which to base local protocols, guidelines and service recommendations (54.2\%);

- (3.8.) by involvement in hospital-based Health Technology Assessments (15.6\%). 
They organize preservation of locally produced knowledge and open access to locally produced content (45.7\%), and support clinicians and researchers in refining their CVs and public expertise profiles $(54.2 \%)$.

Examples: "Searching for evidence for NHS queries (for projects, publications, audits) and for clinicians updating guidelines"; "Producing library-branded evidence packages with citations and some select full text articles (as ILLs) for specific queries"; "Assisting NHS authors with evidence synthesis \& summary by providing basic templates for preparing literature reviews based on refining their results against inclusion / exclusion criteria"; "Systematic searching for HTA, systematic reviews, education on how to search in databases"; "Provided the search and summary for both the national clinical strategy and the local clinical strategy"; "Training courses on how to search information for systematic reviews and guidelines"; Help staff select where to publish and proof read articles for publication. Support ORCID registration".

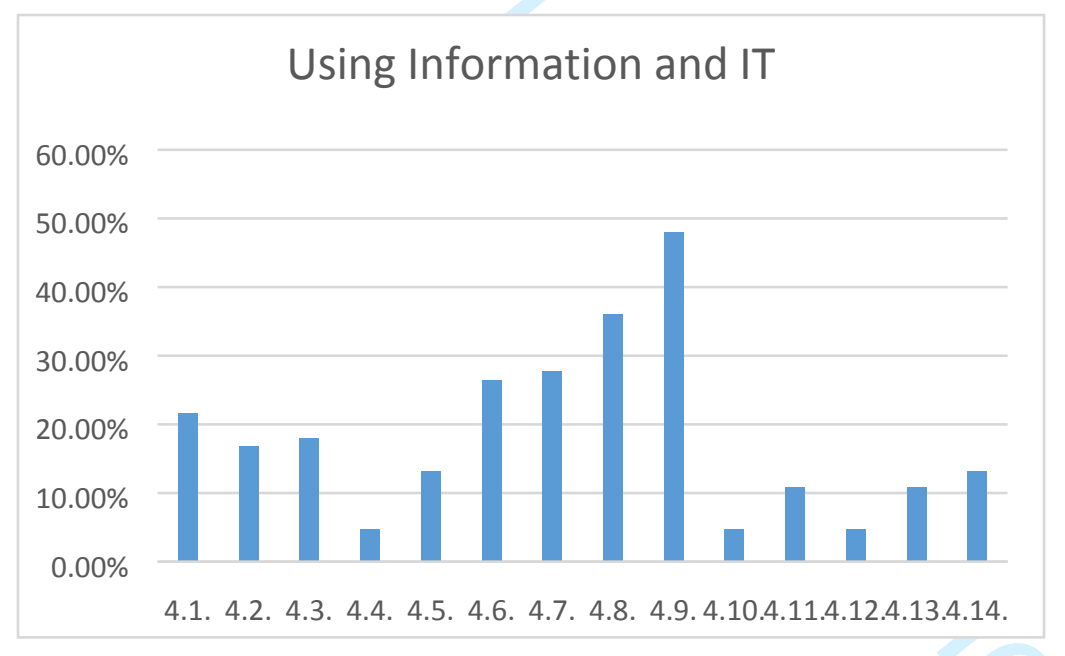

Figure 5. Survey results by activity types in support of Using information and IT

Using information and IT. Though the majority (77\%) support this component of CG, there are only 3 (of 14) types of activities that at least third of libraries are involved in:

- (4.9.) building websites and other information and knowledge tools (48\%);

- (4.8.) building repositories for data and information $(36 \%)$;

- (4.7.) coordinating/ organising discovery systems with a single central index and search interface that allows searching across local library services, subscriptions collections and open access resources $(27.7 \%)$.

Other important role is involvement in data protection:

- (4.1.) data protection / GDPR responsible for organisations (21.6\%);

- (4.6.) identifying, acquiring, and promoting materials on data protection, copyright law, research ethics $(26.5 \%)$.

Much less are involved in planning and policy around information governance:

- (4.2.) writing data management plans and being responsible for data repositories (16.8\%); 
- (4.3.) embedded in multidisciplinary teams in developing organizational policies around IT, information and data management (18\%);

- (4.5.) implementation of national strategies around patient data, knowledge management, IT management (13.2\%);

- (4.4.) board and committee accountability around areas of information governance and ethics $(4.4 \%)$.

New activity for librarians is (4.14.) involvement/leadership in Current Research Information Systems (CRISs) adoption and management (13.2\%).

Examples: "Teaching doctors and health professionals to use new information technologies, collaborating with the IT department to find new ways for clinical information management"; "Library participates in all IT security programs in the country"; "Assisting and designing a data management plan using thesauri"; "Support the redesign of local intranet and roll out of Office 365 , including support of skype training and provision of loanable equipment"; "Support for document best practice and metadata entry in cataloguing organisational documents"; "Some new apps [e.g. Browzine] would not be there if I did not inquire, install, promote and let everyone us it".

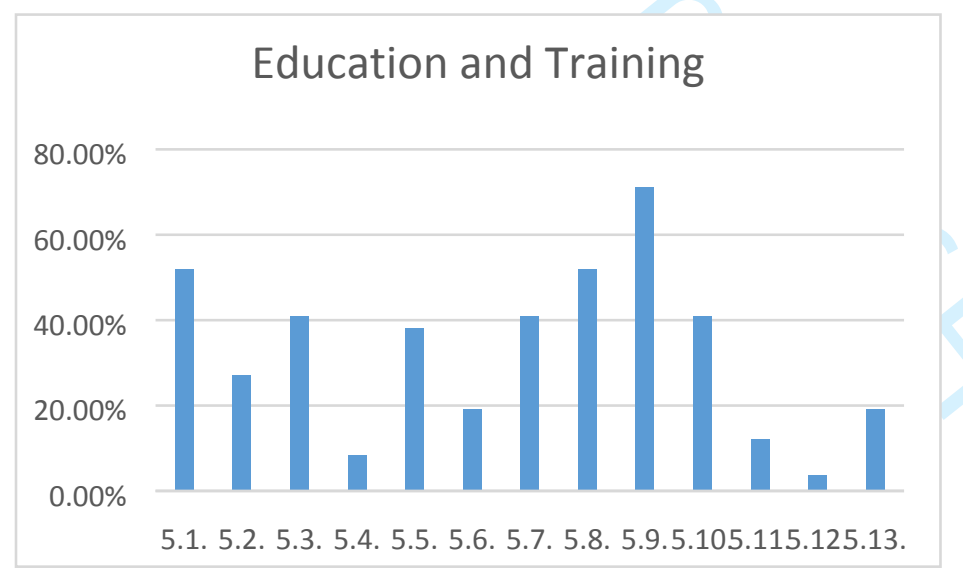

Figure 6. Survey results by types of activities in support of Education and Training

Education and training (lifelong learning). Libraries provide (5.9.) information literacy training (71\%); (5.8.) information skills teaching integrated in certain in-house training (51.8\%); they also develop and provide access to training resources: (5.1.) undertake staff information needs and behavior assessments to develop appropriate and responsive services (51.8\%); access to onsite and Internet-based health learning resources and creating systems for managing learning objects (38\%); develop e-learning modules (40.9\%); and support professional training and development: current awareness services for clinical staff and managers to keep up to date with developments in their fields (40.9\%); identifying, acquiring, and promoting materials to support licensing, certification, and recertification examinations (19.2\%); involvement in planning, development, design, evaluation of their institutions' inter-professional education programs (19.2\%); helping to establish and lead a journal club (12\%). 
Examples: "Embedded in education team and deliver training to junior doctors as part of the curriculum"; "Researching the information behaviour of food scientists so we understand their needs supporting researchers in their bibliographic searches"; "E-learning allows us to teach bigger groups. The e-course lasts for 8 weeks. In the end of the course the doctors and nurses know how to use professional databases and how to search for the necessary information"; "Providing tools for clinicians to track activity in their own field".

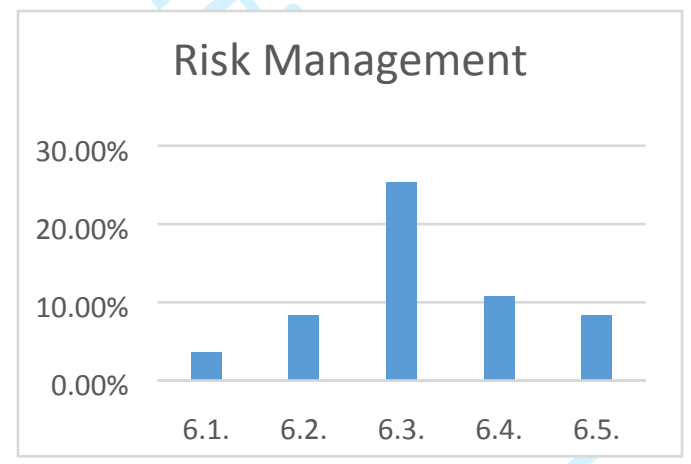

Figure 7. Survey results by activity types in support of Risk Management

Risk management. The highest number of respondents for this component stated literature search activity for patient safety initiatives, practice guidelines review, and root cause analysis (25.3\%). Other types are less represented: participating in clinical activities (executive walk rounds, grand rounds, morning reports, institutional review boards, and mortality and morbidity conferences) $(8.4 \%)$; involvement in co-producing patient education materials about safety $(10.8 \%)$; role in the research needed to ensure safe development of clinical trial protocols $(8.4 \%)$.

Examples: "I follow the publications in the databases dedicated to Risk Management and disseminate them to those responsible"; "Provide a range of literature search and summary services, and work closely with Clinical Governance colleagues to raise awareness of the support available for the creation and renewal of clinical guidelines, as well as providing support of the visualising of the same through our pathway publisher tools"; "Conducting health evidence searches to assist clinicians updating local guidelines and checking available literature for most recent guidelines for specific topics or lack of guidelines if appropriate”.

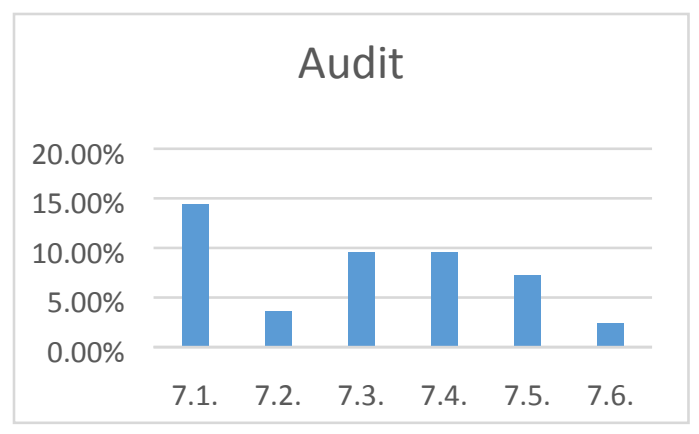

Figure 8. Survey results by activity types in support of Audit

Audit. Third of respondents (32\%) support this component: by assisting staff undertaking clinical audits to differentiate and refine types of research methodology and develop their critical appraisal 
skills (14.4\%); checking of claims made in literature or of material (patient, or promotional) (9.6\%); writing and undertaking evaluation of research projects $(9.6 \%)$.

Examples: "I participate in the creation of questionnaires for clinicians or nurses concerning the construction of measurement scales"; "Clinical audit formulation and retrieval of relevant guidelines/evidence"; "Support evidence search and appraisal skills for clinical audit team and people they refer for support. Support with audit dissemination through the Trust Expo event"; "Leading a chapter of external accreditation related to Patient centeredness".

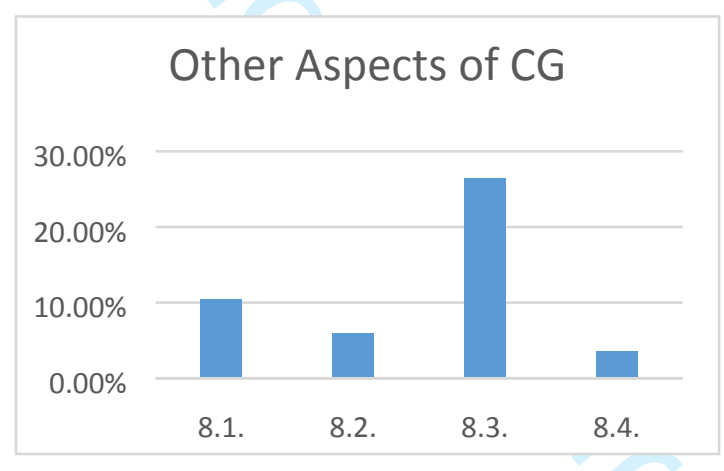

Figure 9. Survey results by activity types in support of other aspects of CG

Other aspects of healthcare organisation governance. Librarians act as advisors on all aspects of information and knowledge matters $(26.5 \%)$ and provide background information for planning teams $(10.4 \%)$.

Examples: "Provides useful information on economic, financial and health management issues"; "I take pride in being able to provide the non-medical employees with information if needed. Our technical or building department might want to know de norm for the thickness of roof slabs or whatever. I will try my best to find it [and usually do]"; "Worked with planning and strategy teams at national, regional and local level to provide evidence for decision making"; "I am available for the participation and creation of limited projects to be submitted to the various company departments"; "The Library member of Emergency Committee"; "We provide a diagnostic tools and outcome measures catalogue, which lists any in use and their copyright status / or costs, we do add some other value e.g. links to articles about the tools and any educational material on their use".

Accountability. Library services connected to performance management tools and activities in health care: providing information on outcome measures and outcome harmonisation initiatives to decision makers (16.8\%); management of key performance measurement tools $(26.5 \%)$.

Most examples are about measuring and making visible research output of their organisations: "Manage Key Performance Indicator for peer-reviewed articles authored inhouse ", , Managing the scholarly output of my organizatione, the impact measures and benchmarking indicators"; "Evaluation of the research quality of the Institute also with bibliometric indicators". 


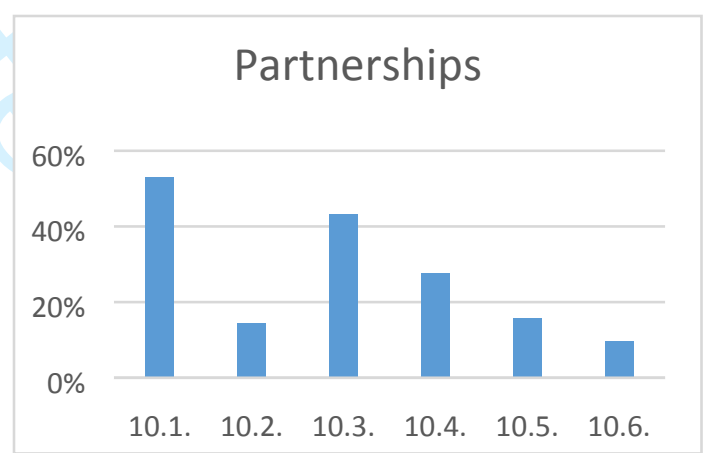

Figure 10. Survey results by activity types in support of Partnerships

Partnerships. Librarians are members of committees and other groups to enable partnerships and delivery of services (53\%); libraries are delivering new, innovative systems and tools to enhance library and information services (43.3\%) and act as a first point of call for advice $(27.7 \%)$.

Examples show partnerships with different types of libraries ("I am part of the Bibliosan system, the network of libraries of Italian biomedical research institutions"; "Taking part in Lithuanian Research Library Consortium. Close cooperation with the Association of Lithuanian Colleges' Libraries"; "Participating in a community of medical libraries and a community with academic libraries. Being able to make use of the library systems of the university library in the same place"; "Practically act in collaboration with high schools and public libraries and universities for common projects evaluating the costs and benefits of the collaboration"; "Transforming local library services to work in a federated way, manage a partnership library with a university and staff from another Trust") and with other types of organizations ("Collaborating with local Biobank on research project - systematic review"; "Member of multidisciplinary team on Learning Disability and provision of health information resources for this client group"; "Provide a copyright first responders service to advice librarians on copyright \& licensing issues - work with the Copyright Licensing Agency \& Library And Archive Copyright Alliance”; "Member of Cancer, member of Alzheimer group”).

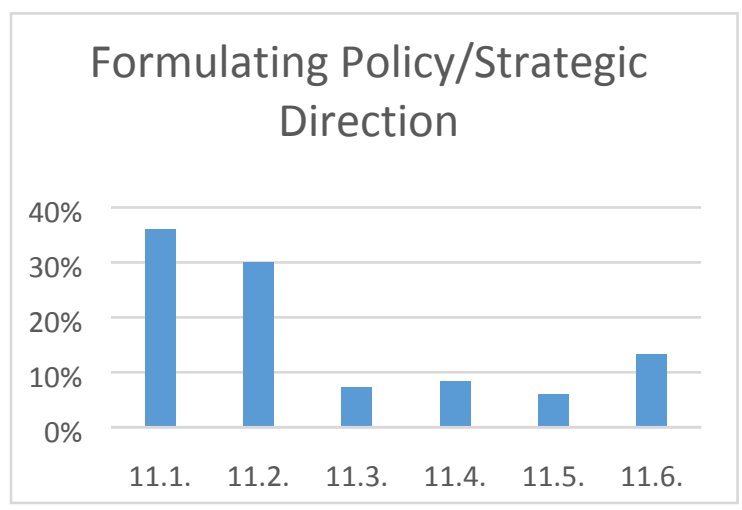

Figure 11. Survey results by activity types in support of Formulating Policy/Strategic Direction

Formulating policy/ Strategic direction. Librarians support this component by responding to consultations and acting in advocacy capacity in library and information matters $(36 \%)$ and by 
working in partnership in developing strategies, national policies, guidelines, standards, manuals and protocols in library and information areas (30\%).

Examples: "Attending regional Clinical Librarian meetings for London / KSS as well as NHS /HE CPD networking events to develop standardised local and regional practices for LKS"; "Providing literature searches for national clinical guideline development; advice and assistance in developing guidelines for literature searching for guidelines”).

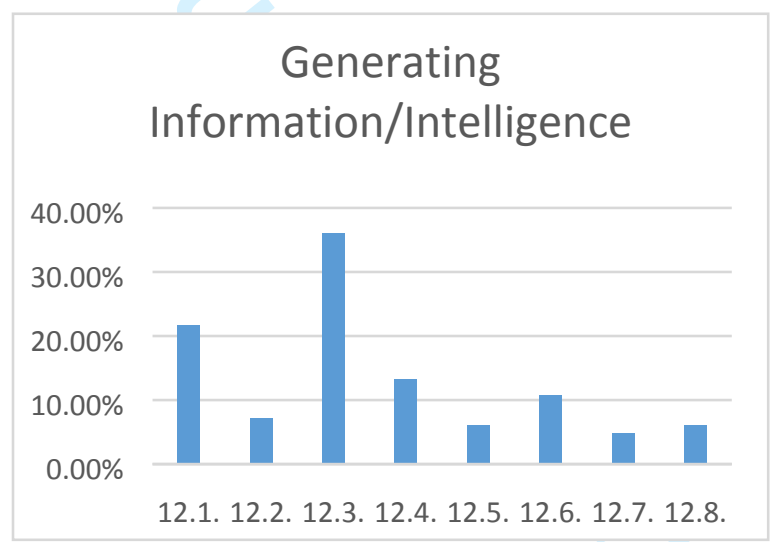

Figure 12. Survey results by activity types in support of Generating Information/Intelligence

Generating information/ Intelligence. Libraries participate in this by developing tools for information and library services and other health care services $(36 \%)$ and by undertaking audits and reviews of library and information services and staff $(21.6 \%)$. On a smaller scale they are involved in the development of Health Technology Assessments, clinical guidelines, health impact assessments, research reports and other projects' reports on the regional and national levels $(13.2 \%)$, in assessments and audits of health care organisations (7.2\%).

Examples: "User surveys and impact forms as well as impact case studies from selection of users of the service to improve LKS offering for NHS staff"; "Creation of Health Education England Value \& Impact Toolkit"; "Work on Terminology (in a committee related to the Minister of Health)".

Organisational adequacy/ System design. Libraries are involved in forward thinking of new developments and requirements (30\%); in developing organisations with continuous evaluation of existing services and future proofing services (12\%); provide support for peer-to-peer learning programs for healthcare professionals (14.4\%). Examples: "Specifically in e-health we look at horizon scanning of the use of technology in health care"; "Participate in Trust's forward thinking event"; "Involvement of Patient Library in developing a cancer patient rehabilitation program".

Participation and consensus. The majority (56.6\%) stated active participation in library and information, as well as health and care, meetings and approaches on a national level. Less are participating in development of consensus statements, standards, processes and strategies to improve health care (14.4\%) and collaborate with patients' associations for developing indicators of surveys aiming to assess patients and citizens' opinion about organization of healthcare services (7.2\%). Examples: "Participation in an international working group for promoting 
information and initiatives in palliative care", "Membership of national and regional groups at which new systems and services are presented and document delivery policy discussed"; "Attending NHS/HE collaborative events and discussion with external colleagues about up-todate LKS service provision via surveys, working groups".

Regulation. This component of HG (includes development and implementation of rules, procedures, decrees, codes of conduct, performance standards, accreditation, licensing/certification) is supported by a $21 \%$ of respondents by: providing information on available health literacy measures to decision makers (18\%) and publishing the Code of Ethics of Health Information Services open to patients and laypeople (6\%). Nobody stated involvement in statutory and regulatory activities. Examples: "Support MDT on learning disability with requirements re health literacy for this group of clients and also contribute to review of lay summaries of patient information for cancer clinical trials as PPI member and library/information professional".

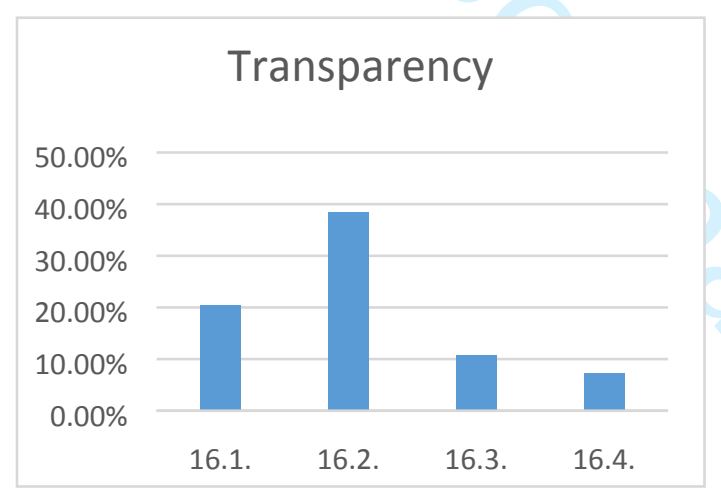

Figure 13. Survey results by activity types in support of Transparency

Transparency. About half of respondents (47\%) support this: by publicising information on library and information services to different health care organisations, target audiences, other libraries (38.5\%), by acting as an independent service for patients and health care organisations without bias $(20.4 \%)$, by actively contributing to organisations' internal procedures around transparency, making recommendations where improvements can be made $(10.8 \%)$, and by promoting the culture of communicating to patients results of their contribution (clinical trials, etc.) (7.2\%). As an additional type of activity one respondent suggested "Developing a system to aid transparency in research to avoid research waste".

Examples: "Our mantra is 'putting the patient first'. Through personal PPI activity promote in partnership with researchers the feedback of lay summary results of clinical trials to research participants, their families and the wider interested public through open access publication"; "We use a variety of tools such as social media and communities of practice to engage with other organsiations and services".

\section{Conclusions}

No previous comparative research has been undertaken before examining the activities and tasks libraries undertake to support clinical and health governance. Libraries in health care organisations 
provide services to a number of stakeholders, e.g. health and care practitioners/specialists, patients and members of the public, researchers, and decision-makers. With responses from 25 European countries, we have identified $\mathrm{C} / \mathrm{HG}$ components in which librarians are involved, with examples that the majority of libraries support clinical effectiveness and research, education and training, patient and public involvement, partnership engagement, participation and consensus, using IT and information, formulating strategic direction, generating information and intelligence etc. Half or nearly half support other aspects of clinical governance, formulating policy/strategic direction. Many also support risk management, audit, transparency, organizational adequacy/ system design, accountability, and regulation. What is clear is that librarians in health and hospital libraries do not only provide services and products within the library environment, but have greater engagement and participation in wider activities of their organisations.

The variety of library activities can be grouped in three main groups:

1. Infrastructure: development of library staff and resources as a basis for support of $\mathrm{C} / \mathrm{HG}$ (e.g. negotiating license agreements for evidence-based information resources, developing standards in library services);

2. Programme management: development of library products and delivering services in support of $\mathrm{C} / \mathrm{HG}$ (e.g. online guides, horizon scanning bulletins; training on scholarly communication topics);

3. Direct participating in $\mathrm{C} / \mathrm{HG}$ (e.g. involvement in community health needs assessment, in ethical committees, in design and facilitation of leadership development programmes, in clinical audits and HTA).

Importantly, our model and responses from European health and hospital librarians suggests that

- library and information staff are embedded in clinical and health governance and should be recognized as experts in this role;

- we can further develop and enhance the traditional library role to a significant knowledge governance core role of every health and hospital organization;

- therefore, formally recognize the librarian role as critical to clinical and health governance;

- develop evaluation tools to measure such impact of the tasks that libraries undertake for clinical and health governance.

We should then replicate these roles, tools and measurements across other libraries in health and care organisations. By doing so, we can promote libraries and librarians as significant actors in organisational governance and enable libraries to develop these emerging roles more formally and reduce risks of closure or funding cuts. These findings will also help decision makers on different levels of the health system to improve their practices by incorporating library functions and services in different components of $\mathrm{C} / \mathrm{HG}$.

We recommend that further research and ongoing dialogue continues to cover the roles of libraries in all European countries via EAHIL, and the rest of the world in collaboration with other library and information associations and membership bodies. 


\section{Acknowledgment}

We are grateful to the focus group members who gave so generously their time: Luc Hourlay, Ivana Truccolo, Maria Garcia-Puente, Štefica Dodig, Lovela Machala Poplašen, Frank Norman.

\section{References}

1. Ayre, S., Brettle, A., Gilroy, D., Knock, D., Mitchelmore, R., Pattison, S., Smith, S., Turner, J. (2018), "Developing a generic tool to routinely measure the impact of health Libraries”, Health Info Libr J., Vol.35 No.3, pp.227-245.

2. Balduini, A., Guizzetti, G., Molinari, S., Truccolo, I., Motta, S., Bernardini, F. and Curti, M. (2013), ["The role of the scientific librarian in HTA: what is the status quo and what are the prospects"], Recenti Prog Med, Vol.104 No.10, pp.542-544.

3. Barbazza, E. and Tello, J.E. (2014), "A review of health governance: Definitions, dimensions and tools to govern", Health Policy, Vol.116, pp. 1-11.

4. Brettle, A., Maden-Jenkins, M., Anderson, L., McNally, R., Pratchett, T., Tancock, J., Thornton, D. and Webb, A. A. (2011), "Evaluating clinical librarian services: a systematic review", Health Info Libr J., Vol.28 No.1, pp. 3-22.

5. Brettle, A., Maden-Jenkins, M. and Payne, C. (2015), "Evaluating the impact of clinical librarian services in the North West", Project Report, University of Salford, Salford, available at: https://tinyurl.com/y76zbhvp (accessed 20 June 2018).

6. Brettle, A., Maden, M. and Payne, C. (2016), "The impact of clinical librarian services on patients and health care organisations", Health Info Libr J., Vol.33 issue 2, pp.100120.

7. Bryant, SL. and Gray, A. (2006), "Demonstrating the positive impact of information support on patient care in primary care: a rapid literature review". Health Info Libr J., Vol. 23 Issue 2, pp.118-125.

8. Halkoaho, A., Luoto, K, Ovaska, T., Saarti, J. and Selander, T. (2018), "Supporting the medical research and daily work at the hospital - analysing the library and information services at the Kuopio University Hospital" , Journal of EAHIL, Vol. 14 No.1, pp. 9-14, available at: http:/eahil.eu/wp-content/uploads/2017/12/journal-12018-web.pdf (accessed 20 June 2018).

9. Madden, A., Collins, P., McGowan, S., Stevenson, P., Castelli, D., Hyde, L., DeSanto, K., O'Brien, N., Purdon, M. and Delgado, D. (2016), "Demonstrating the financial impact of clinical libraries: a systematic review”, Health Info Libr J., Vol. 33 Issue 3, pp.172-189.

10. Marshall, JG., Morgan, JC., Thompson, CA. and Wells, AL. (2014), "Library and information services: impact on patient care quality", Int J Health Care Qual Assur., Vol.27 No. 8, pp. 672-683.

11. Marshall, J G. (1992), "The Impact of the Hospital Library on Clinical Decision Making: The Rochester Study", Bulletin of the Medical Library Association, Vol. 80 No.2, pp. 169-178. 
12. Pearson, B. (2017), "The clinical governance of multidisciplinary care", International Journal of Health Governance, Vol. 22 Issue 4, pp.246-250.

13. Perrier, L., Farrell, A., Ayala, A. P., Lightfoot, D., Kenny, T., Aaronson, E. and Weiss, A. (2014), "Effects of librarian-provided services in healthcare settings: a systematic review", Journal of the American Medical Informatics Association: JAMIA, Vol.21 No.6, pp.1118-1124.

14. Saimbert, MK., Zhang, Y., Pierce, J., Moncrief, ES., O'Hagan, KB. and Cole, P. (2010), "Medical librarians supporting information systems project lifecycles toward improved patient safety", J Healthcare Information Management, Vol.24 No.1, pp.5256.

15. Sutton, A., Grant, MJ. (2010), "Cost-effective ways of delivering enquiry services: a rapid review”, Health Info Libr J., Vol.28, No.4, pp.249-255.

16. Urquhart, C. and Turner, J. (2016) "Reflections on the value and impact of library and information services: Part 2: impact assessment", Performance Measurement and Metrics, Vol. 17 Issue 1, pp.5-28.

17. Urquhart, C. and Tbaishat, D. (2016) "Reflections on the value and impact of library and information services: Part 3: towards an assessment culture", Performance Measurement and Metrics, Vol. 17 Issue 1, pp.29-44.

18. van der Graaf, P., Cheetham, M., McCabe, K. and Rushmer, R. (2018), "Localising and tailoring research evidence helps public health decision making", Health Info Libr J., Vol. 35 No.3, pp.202-212.

19. Weightman, AL., Williamson, J., Library \& Knowledge Development Network (LKDN) Quality and Statistics Group. (2005), "The value and impact of information provided through library services for patient care: a systematic review", Health Info Libr J., Vol. 22 No. 1, pp.4-25. 
Table 1. Components of clinical and health governance and related types of library activities

\begin{tabular}{|c|c|c|c|}
\hline $\begin{array}{l}\text { Clinical } \\
\text { governance } \\
\text { components }\end{array}$ & $\begin{array}{l}\text { Related clinical governance } \\
\text { measures }\end{array}$ & Related library activity types & $\begin{array}{l}\text { Related library } \\
\text { services impact } \\
\text { measures }\end{array}$ \\
\hline $\begin{array}{l}\text { 1.Patient and } \\
\text { public } \\
\text { involvement }\end{array}$ & $\begin{array}{l}\text {-Safeguarding vulnerable } \\
\text { patients; } \\
\text { - Continuous improvement in } \\
\text { Friends \& Family Test scores; } \\
\text { - Continuous improvement of } \\
\text { Patient Reported Experience } \\
\text { Measures; } \\
\text { - Continuous improvement in } \\
\text { complaint response times; } \\
\text { - Education and learning from } \\
\text { complaints and compliments }\end{array}$ & $\begin{array}{l}\text { 1.1. Undertaking patient information needs } \\
\text { assessments to understand further information } \\
\text { needs in specific health areas; } \\
\text { 1.2. Creating resource guides for/ with } \\
\text { patients/carers and practitioners; } \\
\text { 1.3. Finding and providing patient education } \\
\text { materials to reinforce the verbal explanations } \\
\text { and instructions; } \\
\text { 1.4. Involvement in adapting and designing } \\
\text { patient education materials; } \\
\text { 1.5. Sometimes be first contact for a patient } \\
\text { seeking information ('making every contact } \\
\text { count' - MECC); } \\
\text { 1.6. Redirecting certain groups of patients/ } \\
\text { public to better sources of information, } \\
\text { providing contact to get information from other } \\
\text { sources and organisations; } \\
\text { 1.7. Training practitioners on consumer } \\
\text { information and health literacy (understanding } \\
\text { the needs of health literacy-challenged patients, } \\
\text { screening for health literacy, awareness of } \\
\text { consumer health resources, and demonstrating } \\
\text { communication strategies to use in practice } \\
\text { including plain language and active listening); } \\
\text { 1.8. Involvement/ leading systematic assessment } \\
\text { of organization's health literacy attributes } \\
\text { (print and oral communication, navigation, etc.); } \\
\text { 1.9. Information literacy training to the } \\
\text { community (including how to find the most } \\
\text { credible and reliable health and scientific } \\
\text { information); } \\
\text { 1.10. Involving patients and carers in practical } \\
\text { peer training on how to find the most credible } \\
\text { and reliable health information (peer-to-peer } \\
\text { training); } \\
\text { 1.11. Coordinating institutional multi- } \\
\text { professional group (health care workers, } \\
\text { patients and patients' representatives) for } \\
\text { planning patient education activities in a } \\
\text { participative way; } \\
\text { 1.12. Organizing narrative opportunities to } \\
\text { enhance patients and carers telling their } \\
\text { experience (e.g., literary competitions); } \\
\text { 1.13. Enhancing patients' feedback in } \\
\text { implementing patient centered projects; } \\
\text { 1.14. Development, validation and promotion of } \\
\text { tools for evaluating health information for } \\
\text { consumers (transparency, understandability, } \\
\text { clarity, etc.) }\end{array}$ & $\begin{array}{l}\text { - Increased patient } \\
\text { involvement/Shared } \\
\text { decision making; } \\
\text { - Improved patient } \\
\text { care experience; } \\
\text { - Improved patient } \\
\text { access to } \\
\text { information; } \\
\text { - Advice to patient } \\
\text { or carer }\end{array}$ \\
\hline
\end{tabular}




\begin{tabular}{|c|c|c|c|}
\hline $\begin{array}{l}\text { 2. Staffing and } \\
\text { staff } \\
\text { management }\end{array}$ & $\begin{array}{l}\text { - Achieving mandatory } \\
\text { training targets; } \\
\text { - Reducing lost time and staff } \\
\text { sickness due to stress; } \\
\text { - Recruitment, induction, and } \\
\text { retention KPIs; } \\
\text { - Talent mapping, coaching, } \\
\text { mentorship and leadership } \\
\text { development }\end{array}$ & $\begin{array}{l}\text { 2.1. Involvement in staff development; } \\
\text { 2.2. Involvement in leadership development } \\
\text { programmes (design and facilitation) }\end{array}$ & $\begin{array}{l}\text {-Supervision and } \\
\text { leadership of staff }\end{array}$ \\
\hline $\begin{array}{l}\text { 3. Clinical } \\
\text { effectiveness and } \\
\text { research } \\
\text { (evidence-based } \\
\text { practice) }\end{array}$ & $\begin{array}{l}\text {-Improving mortality data and } \\
\text { reducing HCAI; } \\
\text { - Improving clinical outcomes } \\
\text { and PROMs; } \\
\text { - Improving published } \\
\text { research; } \\
\text { - Teams using patient } \\
\text { feedback to improve services; } \\
\text { - Continuous improvement in } \\
\text { timed treatment pathway } \\
\text { targets; } \\
\text { - Clinical benchmarking and } \\
\text { peer-review of service } \\
\text { performance }\end{array}$ & $\begin{array}{l}\text { 3.1. Developing systems to acquire, organize, } \\
\text { and disseminate essential clinical information } \\
\text { resources; } \\
\text { 3.2. Making decisions/suggestions about } \\
\text { subscriptions, negotiating license agreements } \\
\text { for evidence-based information resources for the } \\
\text { organisation; } \\
\text { 3.3. Participating in library purchasing } \\
\text { consortium; } \\
\text { 3.4. Training in quality filtering, critical analysis } \\
\text { of literature, and targeted searching techniques; } \\
\text { 3.5. Developing database guides and } \\
\text { instructions (written, video); } \\
\text { 3.6. Embedding knowledge of clinical evidence } \\
\text { by attending clinical forums/consultations or } \\
\text { supervisions/ continuing professional } \\
\text { development sessions to produce evidence } \\
\text { summaries specific to individual patients, wider } \\
\text { clinical problems or managerial work streams; } \\
\text { 3.7. Search for evidence and clinical guidelines } \\
\text { on which to base local protocols, guidelines and } \\
\text { service recommendations; } \\
\text { 3.8. Involvement in hospital-based Health } \\
\text { Technology Assessments; } \\
\text { 3.9. Pre-packaging information; } \\
\text { 3.10. Undertaking research around evidence } \\
\text { based working methods (e.g. evidence } \\
\text { hierarchies, critical appraisal tools, literature } \\
\text { search protocols); } \\
\text { 3.11. Supporting the research chain within } \\
\text { organisations; } \\
\text { 3.12. Developing search strategies for } \\
\text { organisations; } \\
\text { 3.13. Contributing to preparing grant } \\
\text { applications; } \\
\text { 3.14. Supporting individuals undertaking } \\
\text { research by assisting them to differentiate and } \\
\text { refine types of research methodology and } \\
\text { development, to be aware of research reporting } \\
\text { guidelines, to use and refine their critical } \\
\text { appraisal skills to locate appropriate clinical } \\
\text { literature; } \\
\text { on } \text { sraining, online guides, individual support } \\
\text { manem like ORCID, to use and understand }\end{array}$ & $\begin{array}{l}\text { - Interventions } \\
\text { based on best } \\
\text { practice or current } \\
\text { evidence; } \\
\text { - Imlementing } \\
\text { clinical guidelines; } \\
\text { - Improved quality } \\
\text { of care; } \\
\text { - Meet quality } \\
\text { standards; } \\
\text { - Innovative } \\
\text { practice; } \\
\text { - Diagnosis; } \\
\text { - Choice of } \\
\text { assesssment or test; } \\
\text { - Choice of } \\
\text { intervention; } \\
\text { - Service } \\
\text { development or } \\
\text { delivery } \\
\text { underpinned by } \\
\text { evidence base; } \\
\text { - Revision of care } \\
\text { pathway, } \\
\text { guidelines, } \\
\text { protocol; } \\
\text { - Avoidance of } \\
\text { referral, } \\
\text { readmission, } \\
\text { clinical tests or } \\
\text { hospitalisation; } \\
\text { - Reduce length of } \\
\text { stay; } \\
\text { - Improved health } \\
\text { care outcomes; } \\
\text { - Improved quality } \\
\text { of life for patient or } \\
\text { carers; } \\
\text { - Address } \\
\text { ineqalities in access } \\
\text { to care or unmet } \\
\text { service need; } \\
\text { - Support QIPP } \\
\text { plans (Quality, } \\
\text { Innovation, } \\
\text { - }\end{array}$ \\
\hline
\end{tabular}




\begin{tabular}{|c|c|c|c|}
\hline & & $\begin{array}{l}\text { impact indicators, comply with institutional/ } \\
\text { national open access policies, understand } \\
\text { publishers' licenses and Creative Commons); } \\
\text { 3.16. Assisting individuals with registering and } \\
\text { publishing their research (publishing of research } \\
\text { protocols in various new kinds of journals and } \\
\text { registers, publishing preprints, selecting journal } \\
\text { for publishing); } \\
\text { 3.17. Discovery and preservation of locally } \\
\text { produced knowledge (e.g. collecting and } \\
\text { distributing staff publications), organising open } \\
\text { access to locally produced content; } \\
\text { 3.18. Supporting clinicians and researchers in } \\
\text { refining their CVs and public expertise profiles } \\
\text { (biblio and altmetrics, ORCID identifies, etc) }\end{array}$ & $\begin{array}{l}\text { Productivity and } \\
\text { Prevention); } \\
\text { - Commissioning/ } \\
\text { decommissioning } \\
\text { of services; }\end{array}$ \\
\hline $\begin{array}{l}\text { 4. Using } \\
\text { information and } \\
\text { IT }\end{array}$ & $\begin{array}{l}\text { - Adhering to information } \\
\text { governance requirements; } \\
\text { - Continuously reducing } \\
\text { episodes of harm using } \\
\text { electronic records and } \\
\text { prescribing; } \\
\text { - Personalization of recorded } \\
\text { care plans; } \\
\text { - Shared electronic record } \\
\text { reducing duplication; } \\
\text { - Clinically determined } \\
\text { meaningful data used in } \\
\text { dashboard KPIs }\end{array}$ & $\begin{array}{l}\text { 4.1. Data protection / GDPR responsible for } \\
\text { organisations; } \\
\text { 4.2. Writing data management plans and being } \\
\text { responsible for data repositories; } \\
\text { 4.3. Embedded in multidisciplinary teams in } \\
\text { developing organizational policies around IT, } \\
\text { information and data management; } \\
\text { 4.4. Board and committee accountability around } \\
\text { areas of information governance and ethics; } \\
\text { 4.5. Involvement in implementation of national } \\
\text { strategies around patient data, knowledge } \\
\text { management, IT management, etc.; } \\
\text { 4.6. Identifying, acquiring, and promoting } \\
\text { materials on data protection, copyright law, } \\
\text { research ethics; } \\
\text { 4.7. Coordinating/ organising discovery systems } \\
\text { with a single central index and search interface } \\
\text { that allows searching across local library } \\
\text { services, subscriptions collections and open } \\
\text { access resources; } \\
\text { 4.8. Building repositories for data and } \\
\text { information; } \\
\text { 4.9. Building websites and other information } \\
\text { and knowledge tools; } \\
\text { 4.10. Data analysts and data wranglers; } \\
\text { 4.11. Involvement in data modelling and } \\
\text { statistical work; } \\
\text { 4.12. Embedded in project management and } \\
\text { health information system lifecycle teams; } \\
\text { 4.13. Assisting with integration of evidence- } \\
\text { based resources into electronic patient record } \\
\text { and hospital information systems; } \\
\text { 4.14. Involvement/leadership in Research } \\
\text { Information Management (RIM)/Current } \\
\text { Research Information Systems (CRISs) } \\
\text { adoption and management }\end{array}$ & $\begin{array}{l}\text { - Reduction of } \\
\text { complaints; } \\
\text { - Improved patient } \\
\text { safety; } \\
\text { - Risk management; } \\
\text { - Legal/ ethical } \\
\text { issues }\end{array}$ \\
\hline $\begin{array}{l}\text { 5. Education and } \\
\text { training (lifelong } \\
\text { learning) }\end{array}$ & $\begin{array}{l}\text { - Education and learning from } \\
\text { clinical incidents; }\end{array}$ & $\begin{array}{l}\text { 5.1. Undertaking staff information needs and } \\
\text { behavior assessments to develop appropriate } \\
\text { and responsive services; }\end{array}$ & $\begin{array}{l}\text { - Updated } \\
\text { knowledge and }\end{array}$ \\
\hline
\end{tabular}




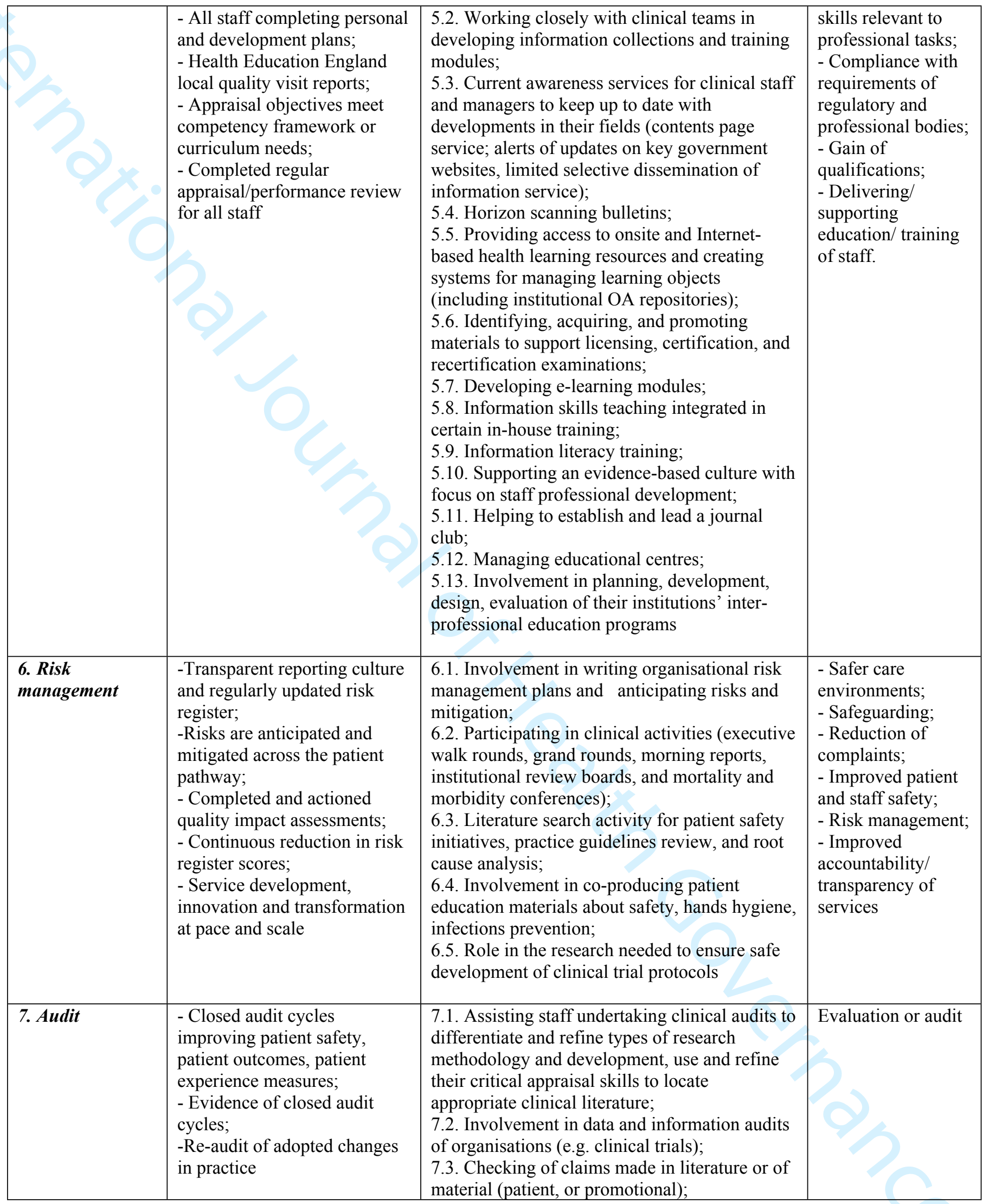




\begin{tabular}{|c|c|c|c|}
\hline & & $\begin{array}{l}\text { 7.4. Writing and undertaking evaluation of } \\
\text { research projects; } \\
\text { 7.5. Being involved as leader of a specific } \\
\text { chapter/ section of external accreditation; } \\
\text { 7.6. Managing patients and public involvement } \\
\text { in self-assessment phase of external } \\
\text { accreditation }\end{array}$ & \\
\hline $\begin{array}{l}\text { 8. Other aspects } \\
\text { of healthcare } \\
\text { organisation } \\
\text { governance }\end{array}$ & & $\begin{array}{l}\text { 8.1. Providing background information for } \\
\text { planning teams; } \\
\text { 8.2. Supporting disaster preparedness and } \\
\text { emergency response programs within the } \\
\text { organisation; } \\
\text { 8.3. Act as an advisor on all aspects of } \\
\text { information and knowledge matters; } \\
\text { 8.4. Member of Internal Ethical Committee }\end{array}$ & $\begin{array}{l}\text { - Support } \\
\text { organizational } \\
\text { financial strategies } \\
\text { (e.g. Cost } \\
\text { Improvement } \\
\text { Programme); } \\
\text { - Demonstrate value } \\
\text { for money/ } \\
\text { providing cost } \\
\text { effective service; } \\
\text { - Business } \\
\text { development (e.g. } \\
\text { income generation, } \\
\text { tenders); } \\
\text { - Legal/ ethical } \\
\text { issues }\end{array}$ \\
\hline $\begin{array}{l}\text { Health } \\
\text { governance } \\
\text { components }\end{array}$ & Related tools & Related library activity types & \\
\hline 9. Accountability & $\begin{array}{l}\text { - Performance-based } \\
\text { contracts; } \\
\text { - Fair competitive elections, } \\
\text { systems of judicial redress, } \\
\text { procedures to combat } \\
\text { corruption; } \\
\text { - Pay-for-performance } \\
\text { techniques; } \\
\text { - Performance measurement } \\
\text { tools and activities }\end{array}$ & $\begin{array}{l}\text { 9.1. Providing information on outcome } \\
\text { measures, outcome harmonisation initiatives to } \\
\text { decision makers; } \\
\text { 9.2. Management of key performance } \\
\text { measurement tools (e.g. for measuring the } \\
\text { research output of an organization) }\end{array}$ & \\
\hline 10. Partnerships & $\begin{array}{l}\text { - Inter-ministerial and } \\
\text { interdepartmental committees; } \\
\text { - Public-private task force; } \\
\text { - Integrated budgets and } \\
\text { accounting, co-funding } \\
\text { arrangements or earmarked } \\
\text { grants; } \\
\text { - Cross-cutting information } \\
\text { education systems; } \\
\text { - Common workforce training, } \\
\text { qualifications, support and } \\
\text { advice; } \\
\text { - Ad-hoc, initiative-specific } \\
\text { committees }\end{array}$ & $\begin{array}{l}\text { 10.1. Member of committees and other groups } \\
\text { to enable partnerships and delivery of services; } \\
\text { 10.2. Writing funding bids and managing } \\
\text { grants; } \\
\text { 10.3. Delivering new, innovative systems and } \\
\text { tools to enhance library and information } \\
\text { services; } \\
\text { 10.4. Acting as first point of call for advice; } \\
\text { 10.5. Establishing and promoting high-impact, } \\
\text { multi-sectoral partnerships and collaboration; } \\
\text { 10.6. Support for cross-cutting information } \\
\text { education systems }\end{array}$ & \\
\hline $\begin{array}{l}\text { 11. Formulating } \\
\text { policy/Strategic } \\
\text { direction }\end{array}$ & $\begin{array}{l}\text { - National health plan; } \\
\text { - National targets, goals and } \\
\text { performance measures; }\end{array}$ & $\begin{array}{l}11.1 \text { Responding to consultations and act in } \\
\text { advocacy capacity in library and information } \\
\text { matters; }\end{array}$ & \\
\hline
\end{tabular}




\begin{tabular}{|c|c|c|}
\hline & $\begin{array}{l}\text { - Multi-year strategic plan; } \\
\text { - Policies, operational } \\
\text { guidelines, training manuals, } \\
\text { protocols; } \\
\text { - Medium-term expenditure } \\
\text { frameworks and national } \\
\text { health accounts; } \\
\text { - Targets-and priority-setting } \\
\text { techniques (e.g. WHO- } \\
\text { CHOICE) }\end{array}$ & $\begin{array}{l}\text { 11.2. Working in partnership in developing } \\
\text { strategies, national policies, guidelines, } \\
\text { standards, manuals and protocols in library and } \\
\text { information areas; } \\
\text { 11.3. Involvement in developing national } \\
\text { strategies around patient data, knowledge } \\
\text { management, IT management; } \\
\text { 11.4. Involvement in localising and tailoring } \\
\text { research evidence to make it useful and usable } \\
\text { for local decision makers (e.g. local } \\
\text { commissioning and planning processes for } \\
\text { public health interventions); } \\
11.5 \text {. Involvement in developing national } \\
\text { strategies behind staff development and } \\
\text { recruitment; } \\
\text { 11.6. Support for developing national healthcare } \\
\text { policies, operational guidelines, training } \\
\text { manuals and protocols }\end{array}$ \\
\hline $\begin{array}{l}\text { 12. Generating } \\
\text { information/ } \\
\text { Intelligence }\end{array}$ & $\begin{array}{l}\text { - Commission reports by } \\
\text { independent researchers; } \\
\text { - Inter-ministerial fact-finding } \\
\text { commissions or task force, } \\
\text { parliamentary investigations; } \\
\text { - Periodic audits, public } \\
\text { expenditure and performance } \\
\text { reviews; } \\
\text { - Health technology } \\
\text { assessments; } \\
\text { - Internationally recognized } \\
\text { tools for conducting a } \\
\text { situation analysis (e.g. HMNb } \\
\text { Health Information Systems } \\
\text { Situation Assessment Tool); } \\
\text { - Health impact assessment; } \\
\text { - Environmental impact } \\
\text { assessment; geographic } \\
\text { information systems, or health } \\
\text { needs assessment; } \\
\text { - Patient reported outcome } \\
\text { measures (PROMs) }\end{array}$ & $\begin{array}{l}\text { 12.1. Undertaking audits and reviews of library } \\
\text { and information services and staff (are they fit } \\
\text { for purpose, impact on population health, } \\
\text { impact on staff development, and impact on } \\
\text { organisations); } \\
\text { 12.2. Involvement in assessments and audits of } \\
\text { health care organisations; } \\
\text { 12.3. Developing tools for information and } \\
\text { library services and other health care services; } \\
\text { 12.4. Involvement in the development of Health } \\
\text { Technology Assessments, clinical guidelines, } \\
\text { health impact assessments, research reports and } \\
\text { other projects' reports on the regional and } \\
\text { national levels; } \\
\text { 12.5. Co-leading projects where PROMs are } \\
\text { implemented; } \\
\text { 12.6. Development, validation and promotion of } \\
\text { tools for evaluating health information for } \\
\text { consumers (e.g. ETHIC - Evaluation Tool of } \\
\text { Health Information for Consumers); } \\
\text { 12.7. Validating tools in different languages to } \\
\text { assess heath literacy level of patients (the use of } \\
\text { the same cross-cultural tools, validated in } \\
\text { different languages, is essential for } \\
\text { implementing multicenter studies to measure } \\
\text { and compare the functional HL levels across } \\
\text { countries); } \\
\text { 12.8. Involvement in community health needs } \\
\text { assessment }\end{array}$ \\
\hline $\begin{array}{l}\text { 13.Organizationa } \\
\text { l adequacy/ } \\
\text { System design }\end{array}$ & $\begin{array}{l}\text {-Implementation or annual } \\
\text { operational plan; } \\
\text { - Monitoring and evaluation } \\
\text { plan; } \\
\text { - Training/personnel manuals; } \\
\text { - Mission/vision statement, } \\
\text { organizational chart; }\end{array}$ & $\begin{array}{l}\text { 13.1. Fundamental involvement in developing } \\
\text { organisations with continuous evaluation of } \\
\text { existing services and future proofing services; } \\
\text { 13.2. Forward thinking of new developments } \\
\text { and requirements; } \\
\text { 13.3. Support for peer-to-peer learning } \\
\text { programs for healthcare professionals }\end{array}$ \\
\hline
\end{tabular}




\begin{tabular}{|c|c|c|}
\hline & $\begin{array}{l}\text { - On-the-spot training } \\
\text { measures; } \\
\text {-Peer-to-peer learning } \\
\text { programs }\end{array}$ & \\
\hline $\begin{array}{l}\text { 14. Participation } \\
\text { and consensus }\end{array}$ & $\begin{array}{l}\text { - Open meetings, public } \\
\text { workshops, national forums, } \\
\text { citizen advisory committees, } \\
\text { citizen juries; } \\
\text { - Satisfaction surveys; } \\
\text { - Sector-wide approaches; - } \\
\text { Consensus conferences; } \\
\text { - National health forums; } \\
\text { - Formal consultations in } \\
\text { drafting legislation }\end{array}$ & $\begin{array}{l}\text { 14.1. Active participation in library and } \\
\text { information, as well as health and care, } \\
\text { meetings and approaches on a national level; } \\
\text { 14.2. Participating in development of consensus } \\
\text { statements, standards, processes and strategies } \\
\text { to improve health care; } \\
\text { 14.3. Active collaboration with patients' } \\
\text { associations for developing indicators of } \\
\text { surveys aiming to assess patients and citizens' } \\
\text { opinion about organization of healthcare } \\
\text { services }\end{array}$ \\
\hline 15. Regulation & $\begin{array}{l}\text { - Rules, procedures, decrees; } \\
\text { - Codes of conduct; } \\
\text { - Performance standards, } \\
\text { accreditation, } \\
\text { licensing/certification; } \\
\text { - Statutory bodies (e.g. } \\
\text { national regulatory agency); } \\
\text { - 'Hard laws' (binding } \\
\text { legislation); 'soft laws' (non- } \\
\text { binding recommendations) }\end{array}$ & $\begin{array}{l}\text { 15.1. Involvement in statutory and regulatory } \\
\text { activities, e.g. checking of medical claims; } \\
\text { 15.2. Publishing the Code of Ethics of Health } \\
\text { Information Services open to patients and } \\
\text { laypeople; } \\
\text { 15.3. Providing information on available health } \\
\text { literacy measures to decision makers }\end{array}$ \\
\hline 16. Transparency & $\begin{array}{l}\text { - Watch dog committees } \\
\text { (facility boards, health } \\
\text { authority, ombudsman, } \\
\text { parliamentary committees); } \\
\text { - Releasing performance } \\
\text { information to providers and } \\
\text { the public; } \\
\text { - Inspectorates, fact finding } \\
\text { commissions; } \\
\text { - Publically available } \\
\text { budgetary and financial } \\
\text { information; } \\
\text { - Citizen report cards; } \\
\text { - Conflict-of-interest boards }\end{array}$ & $\begin{array}{l}\text { 16.1. Acting as an independent service for } \\
\text { patients and health care organisations without } \\
\text { bias; } \\
\text { 16.2. Publicising information on library and } \\
\text { information services to different health care } \\
\text { organisations, target audiences, other libraries; } \\
\text { 16.3. Actively contributing to organisations' } \\
\text { internal procedures around transparency, } \\
\text { making recommendations where improvements } \\
\text { can be made, e.g. publishing results of research, } \\
\text { making data open access, informing senior } \\
\text { management where procedures are inadequate } \\
\text { or services not comprehensive; } \\
\text { 16.4. Promoting the culture of communicating } \\
\text { to patients results of their contribution (clinical } \\
\text { trials, etc.) }\end{array}$ \\
\hline
\end{tabular}

